Journal of Southeast Asian Human Rights, Vol. 2 No. 1 June 2018 pp. 302-322

doi: $10.19184 /$ jseahr.v2i 1.7541

(C) University of Jember \& Indonesian Consortium for Human Rights Lecturers

\title{
Asian Values and Human Rights: A Vietnamese Perspective
}

\author{
Ngo T.M Huong, Vu Cong Giao, Nguyen Minh Tam \\ Vietnam National University Hanoi, Vietnam
}

\begin{abstract}
This paper examines the impact of the ideology of 'Asian Values' on the legal norms and practices that frame the recognition and protection of human rights in Vietnam. Specifically, the paper focusses on the extent to which Asian Values has been deployed to discourage the adoption of international human rights norms and practices in the context of Vietnam's rapid economic development since the mid-1980s. The paper first sketches the adoption of Asian Values in Vietnam's politics and society. It is shown that both the Communist Party of Vietnam (CPV) and the State of Vietnam have clearly articulated Asian Values in formulating their conceptions of human rights. This outcome is argued to result from the fact that Vietnamese political leaders, alike with Lee Kwan Yew in Singapore, the progenitor of Asian Values, have been still strongly influenced by Confucian ideals of governance although the Marxist-Leninist principles on which the current State of Vietnam was based at remain intact. The influence of Asian Values, on the recognition of and support for human rights in Vietnam has, however, been largely negative rather than positive, especially in relation to recognising civil and political rights as codified in universal human rights instruments. Thus, the protection and promotion of human rights in Vietnam, going forward, essentially mandates eliminating the negative influence of Asian Values in the ideology of political leaders and in the wider society.
\end{abstract}

Keywords: Human Rights, Asian Values, Democracy, Constitution, Communist Party, Vietnam

\section{INTRODUCTION}

Support for the ideology of 'Asian Values' in various Asian states has been associated with rising authoritarianism at the expense of democracy and support for human rights. Supporters of the notion of 'cultural relativism' have deployed Asian Values to counter Western conceptions of human rights and to legitimize the unfettered exercise of state power. ${ }^{1}$ Given, however, that Asian states have diverse cultural values, traditions, and political systems, as well as different experiences of colonization by western powers, a single notion of Asian Values is unlikely to embed itself. Historians see Vietnamese culture as embodying a mixture of Confucianism, Buddhism and indigenous value systems; the question then arises as

1 Y Ghai, Human rights and Governance: the Asia Debate, Occasional Paper 4 (Asia Foundation's Center for Asian Pacific Affairs, 1994). 
to whether and to what extent Asian Values are isomorphic with Vietnamese values. A further question concerns the extent to which the adoption by Vietnamese politicians of Asian Values has had negative or positive influences on the formulation of social and political norms in Vietnamese conceptions of human rights.

This paper examines the impact of Asian Values on legal norms and practices concerning human rights in Vietnam. Asian Values is first situated in relation to Vietnam's politics and society, specifically Confucianism and Buddhism. Historical, cultural and political factors that have shaped the current conception of human rights are then examined. Next, conceptions of human rights built into Vietnamese laws are elucidated. The core of the paper is an analysis of human rights language and norms in political ideologies, policies and laws, especially in the various versions of Vietnam's Constitutions. This analysis provides the basis for an argument that the Communist Party of Vietnam (CPV) and the State of Vietnam - the latter being controlled by the former - have held views largely identical to Lee Kuan Yew's formulation of Asian Values with regard to nature and limitations of human rights. It is argued that this confluence of values and practices has been enabled by the influence of Confucian thought on the governance of states and the upholding of ruling powers. Asian Values is nevertheless, in the end, seen merely as a political construction and is not equivalent to Confucian ideas or the other cultural traditions and practices that valorize conceptions of human rights in Vietnam.

\section{CONFUSIANISM, BUDDHISM AND ASIAN VALUES}

Vietnamese culture, alike to some Asian nations, notably China, embodies ideas and practices based on Confucianism, Buddhism and Taoism. Confucianism and Taoism were the dominant ideologies underpinning social practices in China from around 500 BCE. A key concept was the 'ethical leader' who did not require armed force in order to rule. ${ }^{2}$

Confucianism articulates a system of social norms pertaining to the obligations of individuals, social order and political hierarchy. Confucianism notably upholds the primacy of public over individual interests. Confucianism was established as the leading political ideology in a precursor to the modern Vietnamese state, namely the Le Dynasty (1460-97). ${ }^{3}$ Chinese teachings were transmitted to Vietnam and were widely adopted at all levels of government and in the daily practices of Vietnamese people. Rulers encouraged Confucian practices in order to enhance social cohesion. Whilst Asian Values are based on political and cultural sources, the cultural source is most commonly Confucianism; not, however, the original set of ethics advocated by Confucius, but rather the statecentered form adopted by successive Chinese emperors from the second century BCE onwards. At heart, Confucianism is about people and their relationships, and it governs how everyone should act in a hierarchical society. ${ }^{4}$

In conformance with the Confucian ideal of prioritizing public over individual interests, Vietnamese have traditionally seen themselves as members of a family, a village and a

\footnotetext{
Giang Nguyen D C Thu, Lao Tu Tinh Hoa (Tre Publisher, 2013).

Pham Duy Nghia, "Confucianism and the conception of law in Vietnam" (2004) VNU J Sci Leg Stud.

4 Michael D Barr, "Lee Kuan Yew and the 'Asian Values' Debate” (2000) 24 Asian Stud Rev 309.
} 
country; as such a 'collective spirit' is valorized. People who priorities their individual interests are regarded as being selfish. ${ }^{5}$ This explains why individualism is not a strong feature in Vietnamese language and culture.

Vietnamese have also adhered to Confucianism as a political doctrine mandating an elite's right to rule. Le Thanh Ton (the famous King, 1460-1497) codified Confucian values down to the village level. It is unclear, however, whether Vietnam was a Confucian state based on the concept that a state is responsible for society rather one that merely rules society. Over time, in fact, there has been resistance to political reforms by Confucian scholars, as was notably the case in the time of the reformists Ho Quy Ly (1336 - 1407), Nguyen Hue (1753 - 1792), Nguyen Truong To (1830-1871).

As Confucianism was adapted to indigenous Vietnamese culture, laws came to be based on 'moral rules' (Phep vua thua le lang). For much of its history, Vietnam was governed as a feudal system, whereby communal rules were enforceable and recognized by state power (embodied in a King and his lackies). As such, the law never became a supreme arbiter in society. Confucian tradition is well known as implying a 'no law' society. ${ }^{6}$ There were, nevertheless, some notable traditional legal codes (e.g. Le Code, 1460 and Nguyen Code, 1813). The Hong Duc Code, known as National Law (Bo Luat Hong Duc - initiated in the Le Dynasty, 13th-14th CE) was considered to be a progressive legal code which incorporated positive aspects of Confucianism into rules which promoted human values and rights. ${ }^{7}$

Moral issues and traditional values were acknowledged and included respect for the elderly and women, and the responsibility to care for the poor. ${ }^{8}$ The Hong Duc code also recognized rights to private ownership, civil liability compensation, women's inheritance, protection of minority groups and children, and various communal rights. This legal culture was strong enough to impose a rule over society and embodied moral principles. Confucian thought is strongly evident in the code: rulers were morally responsible for the welfare of people and social stability; mandarins were expected to respect and love the people. It is notable that, in terms of human rights, at this time, especially during Le Dynasty (1428-1789), Vietnam had a quite advanced legal system, although it was still heavily influenced by Confucianism. The principles of social order and superior had been set in the governing rules. The Confucianism was strongly influenced in law making and rules where the ruling is based on both law and ethics. ${ }^{9}$ The ruling was made for humanity-based law and rules, that respect rights and respect of people, against the power of the rulers and the public officials for their responsibility to serve people. ${ }^{10}$

Another highly influential set of values in Vietnamese culture derives from Buddhism.

5 David G Marr, "Concepts of 'Individual' and 'Self' in Twentieth-Century Vietnam" (2000) 34:4 Mod Asian Stud at 769-96.

6 Nghia, supra note 3.

7 N M Tuấn, Những giá trị tích cực của Nho giáo trong Bộ luật Hồng Đúc, 4 (Hanoi: Tạp chí Khoa học, Đại học Quốc gia Hà nội, Chuyên san Kinh tế, (2004) at 39-44.

8 Minh Tuan Nguyen \& Van Thang Mai, State and law under Post Le Dynasty in protection of human rights (Nha nuoc va phap luat trieu Hau le voi viec bao ve quyen con nguoi) (National University Publisher, 2016) at 225-226.

9 Ngo Sy Lien, Dai Viet Su Ky Toan Thu (Hanoi: NXB Văn Học, 2009).

10 Nghia, supra note 3. 
Long pre-dating Confucianism, Buddhism came to Vietnam from India around the $1^{\text {st }}$ century CE. Buddhism came to be considered the state religion over the ensuing millennium. Its values were incorporated into daily life and cultural identity in villages but were not imposed by governments. Buddhism enshrines many values - including nondiscrimination, dignity, equality, inalienable 'self' and tolerance (compassion) - that are similar to those underpinning universal conceptions of human rights today. So too are Buddhist values such as freedom of individuals, communities and nations. ${ }^{11}$ These values were prominently expressed in Vietnam's battle for independence from French colonial rule in the $19^{\text {th }}$ century CE; the so-called Renaissance Movement. ${ }^{12}$

Buddhism embodies the notion that each human being is 'a Buddha to be', a notion closely aligned with universal conceptions of human rights, in which individuals are recognized amongst others. For millennium Buddhism was deeply rooted in Vietnam's culture. It was supported and promoted by Kings as a kind of state religion. Buddhism was not then structured and co-existed with animist beliefs and Hinduism. It was deployed to support the state when the state needed to impose its rule and to maintain power. Buddhism came to embody Vietnamese values and national identity. ${ }^{13}$

Buddhism declined during and after the Le Dynasty in $14^{\text {th }}$ century CE, due to the rise of support for Confucianism within the ruling elite. Some of Buddhism's positive values for human rights were not sustained under Confucianism. ${ }^{14}$ The Le Dynasty deployed Confucianism to justify its mandate to govern, and its legal code was based on moral rules. Confucianism is sometimes contrary to liberal ideas concerning human rights: it promotes obeisance to rulers; it accords public order primacy over individual interests; it asserts the responsibility of the state to maintain social order. ${ }^{15}$ Since Vietnam's independence was unilaterally declared in 1946 by Ho Chi Minh the CPV controlled state has followed an antireligion policy wherein Buddhism has been seen as contrary to Marxism dogma.

From time to time in history, rulers have used Confucianism to resist social and political reforms and nationalism. ${ }^{16}$ Several nationalist reformers in colonial times, such as Phan Boi Chau and Phan Chu Trinh, argued against the western notion of human rights in support of their claims to national sovereignty; the rights to life and freedom of the people were considered secondary. ${ }^{17}$

There was a notable decline in adherence to Confucian ideas and practices after Vietnam was colonized by France in the $19^{\text {th }}$ Century CE. This attrition was later accelerated under the Marxist ideology that underpinned the emergence of the modern state of Vietnam. Marxism and Confucianism do, however, have some commonalities, including the primacy of public over individual interests, the importance accorded to collective and harmonious

11 Do Tap Kinh Luc, The Book of Six Ways of Liberation (Second Century AD).

12 Van Ai Vo, "Human Rights and Asian Values in Vietnam" in Hum Rights Asian Values Contesting Natl Identities Cult Represent Asia, Studies in Asian Topics 6 (Routledge, 2000).

13 Ibid.

14 Tuấn, supra note 7.

15 Nghia, supra note 3.

16 In history, the case of Nguyen Truong To (died 1871) who were against to dogmatic intellectual o Confucian dogmatic teaching following Chinese ideology.

17 Vo, supra note 12. 
attitudes in the ways that people treat each other, and the active role of rulers in establishing social order. It may be conjectured that the long-established model of Confucian authoritarian government facilitated the Communist state's being able to restrict recognition of individual rights in the name of collective interests. Under Marxist-Leninist ideology, the term 'social harmony' seems to be mostly pragmatic; an adjunct to improving economic performance, rather than an attempt to replace Marxist-Leninism with the Confucian ideal of an 'harmonious society' and “consensus approach' (as Chinese Communist leaders have done). ${ }^{18}$

\section{ASIAN VALUES AND HUMAN RIGHTS}

Prominent Southeast Asian leaders, notably Lee Kuan Yew and Mahathir Mohammed, have argued that cultural conditions in Asian states, such as those produced by Confucianism and Buddhism, are not conducive to the adoption of notions of human rights and democracy that are prevalent in the West. ${ }^{19}$ Instead, they have argued that, Asian Values should underpin economic development, as they are posited to have done in Japan and Singapore. ${ }^{20}$ Against this Amartya Sen, in discussing human rights vis-a-vis development, has argued that there is no definitive evidence to support arguments about economic growth under different political systems. ${ }^{21}$ Nevertheless, supporters for Asian Values have argued that human rights are alien to the East and have only originated in the historical development of the West. However, as mentioned above in relation to Confucianism and Buddhism, social and political values in many Asian countries, including Vietnam, are consistent with ideas about human rights that have developed in the course of Western developmental history whereby the rule of law has been established. ${ }^{22}$

When Asian Values relate to human rights, the former is often deployed to protect authoritarian governments which aim to limit the rights and liberty of people, especially

18 The concept has been stated in many Party's resolution since the VII the Party Congress (1990). Readall documents at: http://dangcongsan.vn . Even recently the Party made instruction and stress this to its key party members and all other socio-political branches. For example: http://congan.com.vn/tin- chinh/chinh-tri-thoi-su/dat-muc-tieu-thong-nhat-cao-trong-dang-va-dongthuan-xa-hoi_16831.html [accessed 10 April 2017]

19 Fareed Zakaria said that '[...] many Asian dictators used arguments about their region's unique culture to stop Western politicians from pushing them to democratize'. See, Fareed Zakaria, "Asian Values", (2002), online: Foreign Policy <https://foreignpolicy.com/2009/11/09/the-dustbin-ofhistory-asian-values> at 39 .

20 Although Lee Kuan Yew means Asia under Asian Values include Japan, Korea, China, Vietnam, and some other in Southeast Asia (not India and other part of Asia). See, Fareed Zakaria, "A Conversation with Lee Kuan Yew", Foreign Aff (1 March 1994), online: <https://www.foreignaffairs.com/articles/asia/1994-03-01/conversation-lee-kuan-yew> at 109-126. 6

21 Amartya Kumar Sen, Human Rights and Asian Values (Carnegie Council on Ethics and International Affairs, 2003) at 7. He mentioned a list of "helpful policies" to the economic success of countries in East Asia, includes "openness to competition, the use of international markets, public provision of incentives for investment and export, a high level of literacy and schooling, successful land reforms, and other social opportunities that widen participation in the process of economic expansion". Also see: Amartya Sen, Development as Freedom (Knopf Doubleday Publishing Group, 2011).

22 See, Amartya Kumar Sen, Democracy as a Universal Value (1999) at 3-17. 
their political rights. Again, Amartya Sen has argued that whilst the poor may priorities their economic needs they may not want to sacrifice their political rights. ${ }^{23}$ As supporters of Asian Values see it, Asian societies share common values that prioritize collectivism and social order over individualism. Although it cannot be denied that Confucianism and Buddhism have strongly influenced the culture and political life of Japan, China and even Vietnam, Asia is nevertheless highly diverse and cultural preferences may change. The values and experiences in Vietnam may not the same as in Japan or Singapore. ${ }^{24}$ Therefore, it is clear that Asian Values are the political doctrine of some Asian leaders who use it in ideological fights with the West.

There is indeed a question as to the legitimacy of Asian Values in Vietnam. There is a debate as to whether Asian Values exist in Vietnam and are embedded in culture and in legal norms. Asian Values may actually be seen as being alien to both Vietnamese culture and law. Alternatively, it may be argued that Asian Values constitute merely an ethical belief and that the personal ambitions of leader concern power as much as a view about culture. ${ }^{25}$ It is clear enough that Buddhism and Confucianism, mixed with indigenous values, underpinned the development of a modern Vietnamese cultural identity. The corollary has been the reflection in law of humanist values similarly to those defined in the universal declaration on human rights. This is not a Western imposition.

It is doubtful that Asian Values are embedded in culture and law in Vietnam, although there may be connections between Confucianism and the call to support Asian Values by Lee Kuan Yew at the Bangkok Regional Preparatory Meeting to the Vienna World Conference on human rights in 1993. Since then claims to the existence of Asian Values have been advanced under the rubric of cultural relativism to attack the idea of universal human rights. ${ }^{26}$ Vietnam's leaders have evoked Asian Values to support their argument that Western ideas of human rights are incompatible with the Marxist-Leninist ideology and 'Ho Chi Minh thought' that underpin the Vietnamese State. Western ideals of individual rights, including political and civil rights, have been seen as toxic to an ideology that prioritizes economic development, collectivism and political stability. Despite this, Vietnam did sign up to the two core human rights treaties - the ICCPR and ICESCR - in 1982. Against this, however, in concert with other 49 Asian countries, it supported the 1993

23 See, Sen, supra note 22.

24 See, Ibid.

25 T Gammeltoft \& R Hernø, "Human rights in Vietnam: exploring tension and ambiguities" in Hum Rights Asian Values Contesting Natl Identities Cult Represent Asia, Democracy in Asia 6 (London: Curzon Press and Nordic Institute of Asian Studies, 2000).

26 See, Report of the Regional Meeting for Asia of the World Conference on Human Rights, Bangkok, 29 March - 2 April 1993, at: https://documents-ddsny.un.org/doc/UNDOC/GEN/G93/125/95/PDF/G9312595.pdf, [accessed: 20.02.2017], paragraph 8: "Recognize that while human rights are universial in nature, they must be considered in the context of a dynamic and evolving process of international norm-setting, bearing in mind the significance of national and regional particularities and various historical, cultural and religious backgrounds". See, Vienna Declaration and Programme of Action, adopted by the World Conference on Human Rights on 25 June 1993, at: https://documents-dds-

ny.un.org/doc/UNDOC/GEN/G93/142/33/PDF/G9314233.pdf, [accessed: 20.02.2017], paragraph 5: "...] while the significance of national and regional particularities and various historical, cultural and religious background must be borne in mind. 
Bangkok Declaration that affirmed the existence of regional particularities in conceptions of human rights, the principle of non-interference in nation states, and the non-use of human rights as political pressure.

The next section of the paper provides historical background to Vietnam's justification of its distinctiveness regarding human rights in support of the Asian Values 'call'.

\section{HUMAN RIGHTS IN CONTEMPORARY POLITICAL DOCTRINE OF VIETNAM}

During Vietnam's fight for independence, Vietnamese recognized that nationalism was consistent with some human rights values. Ho Chi Minh himself used the language of human rights - in reference to the 1776 American Declaration of Independence - in the Independence Declaration of the Democratic Republic of Vietnam in 1945: "All peoples on earth are equal at birth, all peoples have the right to live, to be happy and free." 27 Vietnam's recent history has, however, witnessed different concepts and understandings of human rights being embodied in law and social practices.

Vietnam's contemporary political history has embraced three main political ideas: Communism, Marxism and Socialism. The level of influence of these ideologies varied over time. In the years, 1945-1954, the nationalist struggle against colonization was contained within a vision (supported by some Vietnamese) of international communism as a guiding light. The period, 1954-1975, was heavily communist (amongst some Vietnamese, particularly in the North) in its ideology and practices promoting national unity and economic management. The period, 1975-1986, was one of reconstruction of the nation towards socialism. In all three periods, political ideology supported authoritarian government. The ideologies and practices of these authoritarian regimes have strongly influenced how human rights are construed in Vietnam.

Vietnam was for most of its long history governed under feudalism and then, for a brief period, was a French colony prior to the August Revolution in $19 \overline{4} 5$ (although in international law it remained a colony until 1954). French colonial legalism imported Western rights-based law and political morality into Vietnam. Many people, during the 1930s, shared anti-colonial nationalist sentiments at large in Southeast Asia. Leaders of movements for political change first looked at Japan as a model for getting away from Western imperialism but later adopted a mélange of Western liberal political thought, aggressive nationalism and Marxism. ${ }^{28}$ The year 1954 saw the departure of the French from Vietnam, followed by the Geneva Treaty that divided Vietnam into two parts. The Democratic Republic of Vietnam (DRV) took power in the North and the State of Vietnam governed in the South - initially under Emperor Bao Dai, as head of state. The South Government adopted forms of parliamentary democracy based on a presidential model of government when Bao Dai was in the South - later on Bao Dai

27 Dinh Vy Nghiem \& Kim Hai Le, The Declaration of Indepedence and the problem of Human rights (Hanoi: Tap Chi Cong San, 1993).

28 R Elson, "Southeast Asia and the colonial experience" in Contemp Southeast Asia (Palgrave Macmillan, 2003). 
ceded government to Diem in 1954. North Vietnam was, ab initio, a Communist quasistate.

Human rights and democracy were intrinsic to nationalist elites exposed to norms and institutions in the West. During the anti-colonization period, accepting democratic norms became an important tactic in nationalist struggles for independence. ${ }^{29}$ Ho Chi Minh incorporated human rights into his 1946 Constitution. Although this first Constitution gave birth to a (self-proclaimed) new republic and supposedly democratic nation, the western idea of human rights remained (and still remains) controversial in Vietnam over the period of heavy Marxist-Leninist ideology of controlling individuals and society. When Vietnam initiated Doi Moi in 1986, political conservatives wanted to attract funds and technology but feared that pressures for political freedom, human rights, the emergence of civil society and wider conceptions of democratic governance would undermine CPV dominance. ${ }^{30}$

During the civil war between North and South Vietnam (1954-1975) communists promulgated values of patriotism and solidarity as the basis for revolution under Marxist dogma. The DRV government further imposed a socialist bias against artistic and literary work and intellectuals who did not hold to Marxism in their ideology. From that point in time, the revolution upheld both nationalism and Marxism as goals. Over 20 years of warfare, with the North/South division eliminated in 1975, and the formation of the modern state of Vietnam, there was only limited implementation of socialist policies. This trajectory was observed in many formerly colonized nations, including the Philippines, Indonesia, Malaysia, Myanmar, and Laos. All had either military regimes or civilian-led authoritarian regimes for their structure of governance. Democracy was therefore notable in its absence. ${ }^{31}$

In the period from 1975 to 1986 , Vietnam faced difficulties under trade embargoes and the economy was proving less robust than anticipated under socialist ideology. By the mid-1980s Vietnam thus began to abandon 'hard core' socialist policies to enable transition towards a market economy when the economic situation had become quite desperate. In the south of the country, transition to socialism was halted. In this context, even Vietnam accessed ICCPR and IECSR in 1982, the language for human rights and other rights such as political and civil rights were not reflected in any official political documents or legal text until 1992 Constitution.

The 1980 Constitution formally brought into being a Vietnamese socialist state, in which the Marxist- Leninist ideology and one political party system were affirmed (in Article 4). The 1992 and 2013 Constitutions, in Article 4, nevertheless reaffirmed the

29 Government of Vietnam, 1946 Constitution. The constitution states many set of human rights in chapter II. $\quad$ Read at http://www.moj.gov.vn/vbpq/Lists/Vn\%20bn\%20php\%20lut/View_Detail.aspx?ItemID=536. [accessed 30/6/2015]

30 Quan Xuan Dinh, “The Political Economy of Vietnam's Transformation Process" (2000) 22:2 Contemp Southeast Asia 360.

31 For example: Indonesian leader Sukarno proposed the idea of 'guided democracy', based on deliberation and consensus rather than on free political contests; Burmese Nationalist leader U $\mathrm{Nu}$ (Prime Minister from 1947 to1958 and again from 1960 to 1962) was attracted to fascism and one party dictatorship, as was Lee Kwan Yew, in Singapore (in power from 1959 to 1990). 
centrality of Marxist- Leninist ideology and the mono leadership of the Vietnamese Communist Party. In other words, since 1980, Vietnam has remained an authoritarian state under a one-party system operating under a state-centric and 'centralized democracy' model. While the nation's constitutions and political ideology embrace Marxist-Leninist notions of justice - an idea of justice derived from collective production and distribution of welfare under socialism - these nets are now being contested under conditions of economic growth but not the priorities for human rights especially civil and political rights. ${ }^{32}$

\section{HUMAN RIGHTS AND THE COMMUNIST PARTY OF VIETNAM}

At the core of Vietnam's political framework is a one-party state as set out in the Constitutions 1980, 1992 and 2013. Vietnam is a Socialist Republic with the Communist Party of Vietnam (CPV) as the ruling party. In practice, Vietnam has been a one-party regime since 1976. All policy making occurs under the control of the CPV and remains within the Party and Party members. The Politburo is the supreme body. Almost all Politburo's 19 members (at present) are also the top leaders of the State. The Politburo sets the direction of the Party and the State. Central Committee usually confirms policy set by the Politburo. All important state positions are held by party leaders or by key cadres.

Doi Moi imitated market-based economic development in 1986, and Vietnam adopted ICCPR and ICESCR since 1982, but still the concept of many individual human rights was alien to the ideology of communism. The concept of many human rights in Vietnam was heavily influenced by the Confucian values, which stressed social duties, hierarchies and obligations. For decades, understandings of human rights have been bound up with contested political positions. ${ }^{33}$ Economic liberalization has had positive effects on human rights and the way economic structure changes with state governance and state-society relations. ${ }^{34}$ The move away from central planning required a reform agenda, including recognition and protection of private ownership of assets, especially private ownership of the means of production; this entailed change to laws and national constitutions. ${ }^{35}$

It can be argued that articulation of, and support for, human rights depends on the ideology of political leaders. As noted, in Vietnam the CPV plays the leading role. The Party has issued statements on human rights that shape the conception of those rights (see Box 1). The guiding principle in the early stages of Doi Moi was that human rights are derive from universal values. Against this liberal formulation, Marxist-Leninist ideology calls for the abolition of "exploitation classes" in the society and notes that human rights are attached to each class; human rights are universal but also particular to traditions,

32 Article 54 of 1980 Constitution emphasizes the principles of collectivity "Moi nguoi vi moi nguoi, moi nguoi vi moi nguoi"

33 Gammeltoft \& Hernø, supra note 25.

34 M Evans, Embedding market reform through statecraft: the case of equitisation in Vietnam (Ho Chi Minh, 2004).

35 John Gillespie, "Changing Concepts of Socialist Law in Vietnam" in Asian Social Leg Change Dyn Vietnam Chin Reform (Australia: Australian National University Press, 2005) at 45-47. 
economic, cultural and social development of each country; human rights are natural rights but need to be provided by law; the state is responsible for protecting rights but rights should be 'harmonized' with national and political stability and the prosperity of the nation; protection and promotion of human rights are objectives of the state, which is needed for fostering the rule of law and industrialization, and modernization of the country. ${ }^{36}$

Recent significant changes in human rights have been codified in constitutions and laws of Vietnam with cautious acceptance and suspicion of the CPV. The CPV initially issued its 'orientation' on the drafting of the 2013 Constitution in a Resolution of its $11^{\text {th }}$ Congress, which states, amongst other things, that "there is an urgent need to amend and improve the 1992 Constitution to adapt to the new conditions." 37 The orientation in this period includes the recognition of human rights, separate from citizen rights and national sovereignty and recognizes that rights are natural rights belonging to everyone. These principles set by the CPV seem not to be connected with Asian Values as was the case in the 1990s and were incorporated in the preparation of the 2013 Constitution; as a result, a new chapter on human rights was developed. ${ }^{38}$ The process of developing the 2013 Constitution engaged diverse and critical views on human rights but at least the demand for a socialist rule of law has opened up official discourse on human rights in political debate and law. ${ }^{39}$ Despite viewpoints on natural rights being put forward by academics and activists, opposing views stress the role of the CPV over the constitution and law. ${ }^{40}$ Moreover, from time to time the claim of Asian Values - communitarianism, cultural and social rights prevailing over individual liberties - are used to deny human rights as natural and individual rights. ${ }^{41}$ In debate between 2011-2012 on constitutional reform, the CPV supported the argument that recognition of human rights should be aligned with international human rights standards: "in order to affirm the important value and role of human rights and citizens' rights in the Constitution and to demonstrate that the CPV and the State will

36 Ref. Communist Party of Vietnam, Instruction no 12/CT/TW dated 12/7/1992

37 Communist Party of Vietnam, Văn kiện Đại hội Đại biểu toàn quốc lần thứ XI [Documents for the XI National Congress of the Communist Party of Vietnam] (Hanoi: Nhà Xuất Bản Chính Trị Quốc Gia [The National Political Publishing House], 2011) 24

38 Report No 11/TTr-UBTVQH13 on the Implementation of the Policy on Research on Amending and Supplementing the 1992 Constitution by the Standing Committee of the National Assembly, dated 8 February 2011 at items 2.5 and 3; See also Report on the Basic Content for Amendment of the 1992 Constitution by the Drafting Committee, dated 27 February 2012 at s 4; and Report on the Draft Amendment to the 1992 Constitution by the Drafting Committee, dated 1 October 2012.

39 Thiem H Bui, "Deconstructing the 'Socialist' Rule of Law in Vietnam: The Changing Discourse on Human Rights in Vietnam's Constitutional Reform Process" (2014) 36:1 Contemp Southeast Asia J Int Strateg Aff 77.

40 Secretary-General Nguyen Phu Trong asserted that the constitution's importance is second to that of the Party's political resolution. See: “Tổng bí thư: 'Đề phòng thế lực muốn xoá bỏ điều 4 Hiến pháp [General Secretary: Take caution of hostile forces' attempt to remove Article 4 of the Constitution]", VnExpress (28 September 2013), online: VnExpress <http://vnexpress.net/tintuc/thoi-su/tong-bi-thu- de-phong-the-luc-muon-xoa-bo-dieu-4- hien-phap-2886937.html>.

41 Binh Minh Pham, "Việt Nam Đối Thoại Với Các Quốc Gia Khác Về Dân Chủ Và Nhân Quyền" (2010) 18 Tap Chi Ly Luan Chinh Tri J Polit Theory. 
consistently respect, preserve, and protect human rights and citizens' rights". ${ }^{42}$

These principles embody characteristics of Asian Values on human rights, by naming the particularities and national rights over individual and natural rights, rights and duties go together for the sake of political stability, and national security. These principles strongly influence legal development in Vietnam. Although some similarities of Asian Values may be noted, these human rights orientations are also rooted in a history of combating external enemies, Vietnamese traditions and culture, the influence of Marxist-Leninist ideology over the first five decades after independence ${ }^{43}$ and the influence of universal human rights system when Vietnam integrate into the global system after Doi Moi. ${ }^{44}$

\section{LEGAL CHANGES AND HUMAN RIGHTS}

Since Doi Moi, economic pressures have been powerful, yet the State has actually engaged in human rights discourses. The Government of Vietnam has entered into many human rights commitments (see Box 2), notably accession to UN human rights instruments (ICCPR, IECSCR) in 1982 and other core conventions. ${ }^{45}$ From 1994 to date, the government has also ratified ILO conventions whereby labor rights have been recognised as human rights and have been adopting into domestic laws. ${ }^{46}$

A second generation of legal changes regarding human rights coincided with Vietnam's deeply embracing global economic integration via WTO accession in 2005; Vietnam needed to meet requirements for WTO membership. Human rights really came to the fore into practice, driving changes in many domestic laws. By complying with WTO rules, Vietnam also needed to implement human rights commitments. All of these moves called for domestic reforms in managing work forces and workers' rights.

The further generation of reform in political ideology and the legal framework, giving even more recognition to human rights, emerged in 2008 when the first

42 UONG Chu Luu, the current vice-president of National Assembly said in: "Những nội dung cơ' bản của Hiến pháp Nước Cộng hòa xã hội chủ nghĩa Việt Nam [Main Contents of the Socialist Republic of Vietnam's Constitution]" (Paper delivered at the National Conference on Implementation of the New Constitution, 8 January 2014) Quang Tri [Quangtri Department of Natural Resources and Environment], online: Quang Tri <http://stnmt.quangtri.gov.vn/ index.php?option=com_content\&view=article\&id=622:nhng-ni-dungc-bn-ca-hin-phap-nc-cng-hoa-xa- hi-ch-ngha-vit-nam\&catid=186:t-chc\&Itemid=179>.

43 See, Karl Marx \& Engels, Complete Works, book 6 (C.Mác - Ăng ghen, Toàn tập, Tập 6) (Hanoi: The National Political Publisher) at 25..

44 See, School of Law, VNU (2011), Textbook on Theories and Laws on Human Rights, ibid, p.413414.

$45 \mathrm{Up}$ to date, Vietnam ratified $13 \mathrm{UN}$ conventions. Read more at

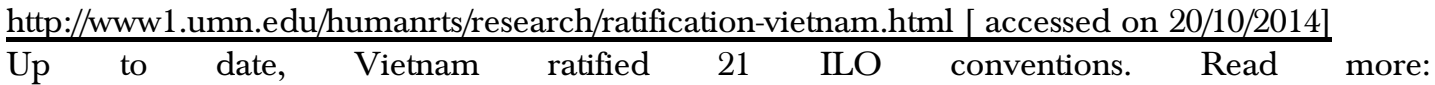
ILO.org at http://www.ilo.org/dyn/normlex/en/f?p=NORMLEXPUB:11200:0::NO::p11200_country_id:103004 [ access at 30/4/2015]. Accordingly, labor law, trade union law, insurance law were amended regarding labor conditions, gender, health and safety at work conditions, collective bargaining etc were introduced. 
Universal Periodical Review was submitted by Vietnam to the UN. With strong political will on the part of Vietnam's leadership on international relations, the nation became a non- standing member of the UN Human Rights Council in November 2013, for the term 2014-2017, and Chair of the ASEAN General Secretariat, for the term 2013-2017. Pressure to adopt and retain commitments to human rights increased. Top political leaders publicly asserted Vietnam's commitments to human rights. ${ }^{47}$ Vietnam has accordingly amended its Constitution that now includes a separate chapter on Human Rights and Basic Rights and Duty of Citizens, effective from 2013. ${ }^{48}$ Following from these shifts, the economic development plan 2011-2020, as the Government's set of policies to orient national development, required that the State create conditions to ensure that human rights are respected. ${ }^{49}$

Box 1: CPV ideas on human rights since Doi Moi (1986)

- Party Congress VI - 1986 states: "Respect and protect citizen's rights"

- The strategy, 1991-2000, was a critical document after Doi Moi, adopted by VIIth Congress of CPV in 1991. It was an ideological breakaway from long term reliance on socialism. The strategy stressed that society is for the people and by people, society is based on value of compassion, and that the relection of central planning was to obtain benefits based on free markets for goods and services

- The central committee of CPV at its VIth session (1987) recognised all three interests separately, including the society's, the collective, the individual.

- The 1991 strategy accepted the principle that "human rights, citizen rights, the freedom of person are provided by law"

- The first recognition of private property rights was in CPV Resolution in VIIIth Congress in 1996.

- Party Congress VII - 1991 then followed by Instruction no. 12 CT/TW on human rights (of the CPV)

- Party Congress VIII - 1996 (page 32) states: "caring for people and community is the whole society's responsibility"

- Party Congress IX (document page 134): "caring for people, protection of rights and benefits of all people, respect and implementation of international treaties on human rights that Vietnam ratifies"

47 Read more at: http://vietnamnet.vn/vn/chinh-tri/202481/thu-tuong-dan-chu-la-xu-the-khong-thedao-nguoc.html “Chúngtôi tin rằngnhânquyền, tự do, dân chủ là xu hướng không thể đảo ngược và là đòi hỏi khách quan của xã hội loài người. VN không phải ngoại lệ, không đứng ngoài xu thế này" - Thủ tướng Nguyễn Tấn Dũng [translation: we believe that human rights, freedom, democracy is the ultimate trend of people and soceity. Vietnam is not exceptional outside this trend] [accessed on 18 Oct 2014]

48 Government of Vietnam. 2013 Constitution. Chapter 2. Human rights and citizen's rights

49 Government of Vietnam. Socio Economic Development Plan 2011 - 2020 states "it aims to ensure human rights and citizen rights for overall development" [original text: Phải bảo đảm quyền con người, quyền công dân và các điều kiện để mọi người được phát triển toàn diện.] Read more

at: http://123.30.190.43:8080/tiengviet/tulieuvankien/vankiendang/details.asp?topic=191\&sub topic $=8 \&$ leader_topic $=989 \& i d=$ BT531160686 $[$ accessed on 18 Oct 2014] 
- Congress Party VII - 1991, Instruction 12-CT/TW of the CPV's Secretary Board shows the Party' direction and perception on human rights to be more comprehensive, in which human rights are viewed as human values but attached to nationalism (national rights and sovereignty). The instruction justifies human rights to be attached to history, tradition and depend on economic and cultural development level of the nation. Therefore, it can not be copied from any state model to others.

- The first recognition of property rights of private sector was stated in the CPV Resolution in VIII Congress in 1996.

- In the Xth Congress in 2006, the CPV called for political stability and harmonious in the society.

- 2013 Report No 11/TTr-UBTVQH13 on the Implementation of the Policy on Research on Amending and Supplementing the 1992 Constitution by the Standing Committee of the National Assembly, dated 8 February 2011

Source: The Communist Party of Vietnam. All official documents: http://www.dangcongsan.vn/tu-lieu-van-kien/van-kien-dang.html

Box 2 Commitments and requirements under international and regional rules affecting Vietnam

\begin{tabular}{|c|c|}
\hline $\begin{array}{l}\text { UN Human } \\
\text { Rights } \\
\text { Mechanism }\end{array}$ & $\begin{array}{l}\text { After reunion in } 1975 \text {, Vietnam joined United Nation in } 1977 \text {, } \\
\text { since then Vietnam joins many international conventions and } \\
\text { treaties on human rights. } \\
\text { Vietnam has ratified } 13 \text { UN human rights conventions, including } \\
\text { ICCPR and IECSCR in } 1987 \text {. } \\
\text { Vietnam became a non-standing members of Human Rights } \\
\text { Council in } 2012 \text {. } \\
\text { Vietnam, in its UPR reports of } 2008 \text { and } 2013 \text { made commitments } \\
\text { to recognising human rights. } \\
\text { Vietnam has made report on IECSR in } 1993 \text { and only in } 2014 \text {. } \\
\text { Constitution of Vietnam was amended in } 2012 \text { to incorporate a } \\
\text { human rights chapter. }\end{array}$ \\
\hline ASEAN & $\begin{array}{l}\text { ASEAN Declaration 1965: member nations committed to } \\
\text { appraise the value of harmony and consensus. } \\
\text { ASEAN Human Rights Declaration, 2012, declares "respect for } \\
\text { and promotion and protection of human rights and fundamental } \\
\text { freedoms, as well as the principles of democracy, the rule of law } \\
\text { and good governance, respect for and promotion and protection } \\
\text { of human rights and fundamental freedoms, as well as the } \\
\text { principles of democracy, the rule of law and good governance; } \\
\text { recognizing freedom of peaceful assembly, right to work, to the } \\
\text { free choice of employment, to enjoy just, decent and favorable } \\
\text { conditions of work and to have access to assistance schemes for }\end{array}$ \\
\hline
\end{tabular}




\begin{tabular}{|l|l|}
\hline & the unemployed, the right to an adequate \\
standard of living for himself or herself and his or her family."50 \\
In 2007, Vietnam agrees on ASEAN Charter and ratify ASEAN \\
charter on 6/3/2008 \\
In 1995, Vietnam officially becomes members of ASEAN \\
In 2010 Vietnam held rotating chair of ASEAN and in 2012 \\
Vietnam representative became the ASEAN Secretary General
\end{tabular}

As Vietnam participated in UN and other regional forums on human rights, the language of human rights began to be used from 1993. In that year Vietnam participated in debate about Asian Values during the preparatory conference in Bangkok and subsequently signed the Bangkok Declaration ${ }^{51}$ which stressed respect or national sovereignty and non-interference by external powers including the use of political pressure in support of human rights (para 5). "[T] he significance of national and regional particularities and various historical, cultural and religious backgrounds" was emphasizes (para 8). ${ }^{52}$

Although that human rights discourse in Vietnam has not always been based on a shared understanding of universal human rights, in the Constitutions of Vietnam many human rights elements are to be found. Vietnam had new and revised Constitutions in 1946, 1959, 1980, 1992 and 2013. Until 1992, the Constitutions were heavily influenced by Marxist-Leninist ideology and a socialist human rights tradition was established whereby human rights were equated to a concept of citizens' rights. Opposing ideas and ideologies were at play when the 1946 Constitution was being made. ${ }^{53}$ This Constitution $^{54}$ had only 70 Articles but citizen rights were provided for in 18 Articles and accorded priority in Chapter II, "Rights and Duties of Citizens." The Constitution also established a liberal foundation for the recognition, respect, and protection of natural human rights - as is distinct from socialist positive rights - although these were included much later. ${ }^{55}$

During the constitution building process ideas, distinction between "rule of law" and "rule by law", "liberal democracy" and "socialist democracy", "Western principles"

$50 \quad$ Ref. $\quad$ http://www.asean.org/news/item/declaration-of-asean-concord-ii-bali-concord-ii http://www.asean.org/news/asean-statement-communiques/item/asean-human-rights-declaration

51 Final Declaration of the Regional Meeting for Asia of the World Conference on Human Rights and the Vienna Declaration and Programme of Action, 1993. http://www.ohchr.org/EN/AboutUs/Pages/ViennaWC.aspx [accessed 10 March 2017]

52 Report of the Regional Meeting for Asia of the World Conference on Human Rights, ibid.

53 Ngoc Son Bui, Lại Bàn Về Bài Học Từ Hiến Pháp 1946 [Revisiting Lessons Learnt from the 1946 Constitution] (Tạp chí Tia sáng [Tia sang Magazine], 2001).

541946 Constitution of the Democratic Republic of Vietnam (adopted 9 November 1946) [1946 Constitution].

55 Xuan Duc Bui, "Chapter on Fundamental Rights and Duties of Citizens in the 1992 Constitution: Shortcomings, Limitations, and Solutions" in Const Theor Pract (Hanoi, Vietnam National University: Hanoi Press, 2011) at 615-617. 
and "Asian values" were debated. ${ }^{56}$

Towards the end of the 1980s, a strong model of socialist citizen's rights had been firmly established through iterations of constitutions. The 1959 Constitution was an extension of the 1946 Constitution inasmuch as it contained 21 Articles related to Citizen Rights and Duties. The 1980 Constitution was one for a unified Vietnam, which inherited and built on the two previous constitutions. It had 29 Articles specifying Citizen Rights. Provisions on human rights were only placed in Chapter III of the 1959 Constitution and in Chapter V of the 1980 Constitution and many rights were omitted. Moreover, even within that narrow socialist legal model, cultural and economic rights were emphasized more than individual civil and political rights. The constitutions appraised the values of collective mastery in that communitarian or social interests should prevail and the rights and duties of citizens should correspond to their position vis- à-vis the state. ${ }^{57}$

The changes in these four versions of the constitution appear to reflect the ideological fluctuations of the Vietnamese legislators. For example, the abolition of the right to private ownership, originally provided for in the 1946 Constitution, and the introduction of new economic, social, and cultural rights in the 1959 and 1980 Constitutions demonstrate Vietnam's growing acceptance of socialism.

A significant addition to the 1992 Constitution was the explicit recognition of the principle of respect for human rights in Article 50. ${ }^{58}$ The 1992 Constitution for the first time provided a concept of human rights and used the term of human rights. Other human rights in the field of society, economy and culture were also recognized and the right to private ownership was restored. ${ }^{59}$ The market-based economy initiated by Doi Moi, as noted above, saw Vietnam's deepening engagement with the international community. Vietnam's leaders accordingly came to accept a broader idea of universal human rights and accepted that individualism and private ownership of property were linked. Although there have been efforts to put human rights more explicitly in the text of the constitution, the shift away from a socialist oriented economy has been reflected in the recognition of more rights of citizens in their relations with the state. Check and balance mechanisms to protect citizens against arbitrary state power have been provided: "all citizens are equal before law, citizens have rights to participate in social affairs, and to participate in discuss general issues of the society." The language describing human rights and the state in the 1992 Constitution did not however fully

56 C G Vu \& K Tran, “Constitutional Debate and Development on Human Rights in Vietnam” (2016) 1 Asian J Comp Law.

57 Van Hieu Dam, Fundamental Rights and Duties of Citizens (Hanoi: Legal Publishing House, 1981).

58 Article 50 of the 1992 Constitution, supra note 2, states: "In the Socialist Republic of Vietnam, human rights in all respects, political, civic, economic, cultural and social are respected, find their expression in the rights of citizens and are provided for by the Constitution and the law"

59 This demonstrates the comparative importance of human rights in the 1946 Constitution. More importantly, a number of fundamental civil and political rights in the 1946 Constitution, namely the right to private ownership of property (Article 12), the right to open private schools (Article 15), the right to free elections (Article 17), the right to dismiss elected deputies (Article 20), and the right to approve constitutional amendments (Articles 21 and 70) were neglected or omitted in subsequent versions 
reflect international conceptions of human rights. Many local observers have argued that the 1992 Constitution implied that human rights are a "gift" of the state, not natural rights. Specifically, 33 provisions in Chapter V of the 1992 Constitution appeared to position the state as the grantor of rights through phrases such as "the State ensures", "the State plans to", "the State regulates", "the State requests", "the State preserves..". 60 The 1992 Constitution was still heavily influenced by Marxist ideology that emphasized the role of the state and also the Confucian notion that citizens are dependent on the state. ${ }^{61}$

As mentioned above, since 2011 there has been a strong push from the CPV to build new rules of law reflecting global economic engagement into a new Constitution. ${ }^{62}$

Chapter V of the 1992 Constitution was titled: "Rights and Obligations of Citizens." It was moved to form Chapter II of the 2013 Constitution and is now titled "Human Rights, Citizens' Basic Rights and Obligations." In addition, in order to acknowledge human rights and citizen rights separately, under the 2013 Constitution, human rights and citizens' rights are no longer deemed "bestowed" or "gifted" by the state to the people. Instead, the 2013 Constitution takes the approach that human rights are

natural rights and that the state is obligated to recognize, protect, and ensure the implementation of such rights, as provided for in Articles 3 and $14 .{ }^{63}$ The 2013 Constitution explicitly provides new rights that align with the adoption of international human rights instruments. ${ }^{64}$ However, the Constitution still does not recognise a number of important rights and freedoms both as per stated in ICCPR and IECSR such as right to strike, right to join trade union, freedom of thought etc. ${ }^{65}$

60 Ngoc Son Bui, Tien Dat Bui \& Dang Dung Nguyen, Findings Report of the Research on "Human Rights in the Constitutions of Vietnam" (Vietnam National University Hanoi, 2010) at 149.

61 Bui, Bui \& Nguyen, supra note 60.; NGUYEN Dang Dung \& BUI Tien Dat, "Cai Cach Che Dinh Quyen va Nghia Vu Co Ban Cua Cong Dan Trong Hien Phap 1992 Theo Cac Nguyen Tac Ton Trong Quyen Con Nguoi [Reforming Provisions on Rights and Duties of Citizens in the 1992 Constitution According Principles of Human Rights Protection]" in NGUYEN Dang Dung et al, eds, Amending the 1992 Constitution: Theoretical and Practical Issues (Hanoi: Hong Duc Publisher, 2012) vol 2, 14 at 24.

62 Trong Nghia Truong, "The Rule of Law in Vietnam: Theory and Practice" in Rule Law Perspect Pacfic Rim (Mansfield Center for Pacific Affairs, 2000) at 123 - 141.

$63 \mathrm{Vu} \&$ Tran, supra note 56.

64 The 2013 Constitution recognizes a number of new rights, including the right to life (Article 19), a citizens' right not to be expelled or extradited over to another country (Article 17), the right to donate human body parts and the human body (Article 20), the (inviolable) right to privacy (Article 21), the right to legal residence (Article 22), the right to social security (Article 34), the right to marry and divorce (Article 36), the right to experience and approach cultural values, to take part in cultural life, and to use cultural facilities (Article 41), the right to determine one's nationality, to use one's mother language, and to select the language of communication (Article 42 ), and the right to live in a fresh environment (Article 43).

65 To be imprisoned on the grounds of inability to fulfill contractual obligations (ICCPR, Article 11), the right to recognition as a person before the law (ICCPR, Article 16), the right to strike (ICECSR, Article 8.1), the right to form and join trade unions (ICCPR, Article 22; ICESCR, Article 8.2), freedom of thought (ICCPR, Article 18.1), and the right to hold opinions without 
Still there are barriers, based in the fear of opening up space for opposing the regime and potential instability of the regime. Despite these rights not being recognized in the constitution, the constitution still gives space for more laws to be provided such as law on demonstration, law on association, law on referendum etc. to put human rights in practice. ${ }^{66}$ The state has opened up space for negotiation with citizens and acceptance of human rights even if the current version of the constitution remains less than fully aligned with international standards.

Amendments of the Constitution and laws in Vietnam since 1946 reflect fluctuations the language of human rights. Constitutions have changed to expand recognition of human rights not so much because of the persistence of Confucianism values, or indeed other traditional values, but because of the leading ideologies brought into leadership and CPV, once dominated by Marxism-Leninist within the framework of socialist oriented state. The influence of Asian Values has been randomly mentioned by some of the top leaders to argue for a contraction in the definition of human rights; justified in the name of political stability. But Asian Values have not been a dominant rubric in constitutional and legal development because Vietnam has accepted the need to be open to more diverse views consequent with engagement in the international community which requires compatibility with international human rights standards and mechanisms.

\section{CONCLUSION}

Asian Values have influenced the human rights discourse and legal development in Vietnam. In the pre-cursors to Asian Values, Buddhism and Confucianism have conditioned Vietnamese societies that have been strongly influenced by it to accept the principles of Asian Values. For a long period even after independence, human rights as per universal conception encoded in international human rights laws were not clearly upheld in legal development or in the in the rhetoric of national leaders. The ideological barriers were

In political discourse, however, the notion that there is an identifiable and important set of Asian Values has never been strongly articulated in political ideology and debates. As the results, Asian Values have not been defined as key considerations in state/CPV guidance to society. Asian Values have, however, appeared in some arguments by leaders seeking to counter Western ideas and practices of human rights. Such arguments have been based on notions of regional or national particularities of culture and traditions; they have not been strong and persistent in supporting retention of a version of Asian Values in debates on human rights in Vietnam.

Certain counter arguments, denying that human rights are universal, have comes from leaders, and are randomly found in contemporary national development debates. However, the main barriers to human rights being recognized in law and being respected and protected in practice are based in the strong influence of Marxist-Leninist ideology that

interference (ICCPR, Article 19.1).

66 Cong Giao Vu, Minh Tuan Nguyen \& Minh Tuan Dang, Report Assessment of the Legislative Development Process in Vietnam since adoption of 2013 Constitution (Hanoi: National Legislative Development Project, 2004). 
accords power to a ruling CPV elite. Reformists have advocated for modernization of political ideas since Vietnam shifted to a market-based economy and integration with global markets and communities. But such voices have not influenced the conservative elite who believes that universal human rights undermine their hold on power.

Although the notion of universal human rights is relatively new to Vietnamese, the nation's cultures have always espoused cognate values, in some respects. Tolerance of difference, for example, is embedded in culture from religious and ideological sources, notably Buddhism and Confucianism. It is accordingly incorrect to argue that such traditional and communal or indigenous values are incompatible with human rights values, or that Asian Values embedded in Vietnamese society are not compatible to the universal human rights. Support for pluralism and diversity has been part of Vietnamese history and development. Vietnam is not a secular society but accepts diversity in thought and ideology. Buddhism and Confucianism dominated at various times and their embedded cultural influences remain strong in the present day.

It is also not correct to assume that support for the exercise of human rights depends on economic and social development, or that a society should prioritize economic growth over human rights as argued by Lee Kuan Yew and other political leaders. In fact, the accession of Vietnam in international human rights mechanism such as ratifying ICCPR and IECSR in 1982 was the starting point to adopt the universal human rights conception. Universalist notions have taken hold as Vietnam has engaged with the global economy and global institutions.

Newer ideologies, notably Marxism-Leninism, have dominated policies and law for several decades for socialism. Oddly enough, socialism has some similar values with the notion of Asian Values but Asian Values are not often referred to in setting policy or law. The new Constitution in 2013 recognizes a wider range of human rights as similar language with international standards. But the implementation and enforcement of such human rights remain in the practice and in the will of those in power who ever claimed on Confucianism and kind of Asian Values conception in order to hold social orders and political stability. The process of political reform in support of human rights and democratization in Vietnam may be slow due to the persistence of power holders relying on claims of Confucianism and Asian Values. These ideas are negative to promote human rights in practice even human rights are encoded in the constitution and law as the universal language. Nevertheless, the pressure to recognize human rights in law and practice has come from internal supporters through dialogue and integration with international communities.

Regime change will not result from external influences per se but rather from gradual change within the authoritarian and strong state. ${ }^{67}$ Changes may come from an increasingly active and diverse society pushing for the widening of political space and the adoption of a wider range of human rights standards. This may be a coming subject on how human rights are promoted and protected in practice while human rights are recognized by law, against certain group of conservatives holding Confucianism and Asian Values ideas.

\section{BIBLIOGRAPHY}

${ }^{67}$ Gainsborough, M. Vietnam, Rethinking the State (Zed Books. London \& New York. 2010). 
Bui, Ngoc Son. Lại Bàn Về Bài Học Tù Hiến Pháp 1946 [Revisiting Lessons Learnt from the 1946 Constitution] (Tạp chí Tia sáng [Tia sang Magazine], 2001).

Bui, Ngoc Son, Tien Dat Bui \& Dang Dung Nguyen. Findings Report of the Research on "Human Rights in the Constitutions of Vietnam" (Vietnam National University Hanoi, 2010).

Bui, Thiem H. "Deconstructing the 'Socialist' Rule of Law in Vietnam: The Changing Discourse on Human Rights in Vietnam's Constitutional Reform Process" (2014) 36:1 Contemp Southeast Asia J Int Strateg Aff 77.

Bui, Xuan Duc. "Chapter on Fundamental Rights and Duties of Citizens in the 1992 Constitution: Shortcomings, Limitations, and Solutions" in Const Theor Pract (Hanoi, Vietnam National University: Hanoi Press, 2011).

Dam, Van Hieu. Fundamental Rights and Duties of Citizens (Hanoi: Legal Publishing House, 1981).

D Barr, Michael. "Lee Kuan Yew and the 'Asian Values' Debate" (2000) 24 Asian Stud Rev 309.

Dinh, Quan Xuan. "The Political Economy of Vietnam's Transformation Process" (2000) 22:2 Contemp Southeast Asia 360.

Elson, R. "Southeast Asia and the colonial experience" in Contemp Southeast Asia (Palgrave Macmillan, 2003).

Evans, M. Embedding market reform through statecraft: the case of equitisation in Vietnam (Ho Chi Minh, 2004).

Gammeltoft, T \& R Hernø. "Human rights in Vietnam: exploring tension and ambiguities" in Hum Rights Asian Values Contesting Natl Identities Cult Represent Asia, Democracy in Asia 6 (London: Curzon Press and Nordic Institute of Asian Studies, 2000).

Ghai, Y. Human rights and Governance: the Asia Debate, Occasional Paper 4 (Asia Foundation's Center for Asian Pacific Affairs, 1994).

Gillespie, John. "Changing Concepts of Socialist Law in Vietnam" in Asian Social Leg Change Dyn Vietnam Chin Reform (Australia: Australian National University Press, 2005).

Lien, Ngo Sy. Dai Viet Su Ky Toan Thu (Hanoi: NXB Văn Học, 2009).

Luc, Do Tap Kinh. The Book of Six Ways of Liberation (Second Century AD). 
Marr, David G. "Concepts of 'Individual' and 'Self' in Twentieth-Century Vietnam" (2000) 34:4 Mod Asian Stud 769.

Marx, Karl \& Engels. Complete Works, book 6 (C.Mác - Ăng ghen, Toàn tập, Tập 6) (Hanoi: The National Political Publisher).

Nghia, Pham Duy. "Confucianism and the conception of law in Vietnam" (2004) VNU J Sci Leg Stud.

Nghiem, Dinh Vy \& Kim Hai Le. The Declaration of Indepedence and the problem of Human rights (Hanoi: Tap Chi Cong San, 1993).

Nguyen, Minh Tuan \& Van Thang Mai. State and law under Post Le Dynasty in protection of human rights (Nha nuoc va phap luat trieu Hau le voi viec bao ve quyen con nguoi) (National University Publisher, 2016).

Pham, Binh Minh. "Việt Nam Đối Thoại Với Các Quốc Gia Khác Về Dân Chủ Và Nhân Quyền” (2010) 18 Tap Chi Ly Luan Chinh Tri J Polit Theory.

Sen, Amartya. Development as Freedom (Knopf Doubleday Publishing Group, 2011).

Sen, Amartya Kumar. Democracy as a Universal Value (1999).

- Human Rights and Asian Values (Carnegie Council on Ethics and International Affairs, 2003).

Thu, Giang Nguyen D C. Lao Tu Tinh Hoa (Tre Publisher, 2013).

Truong, Trong Nghia. "The Rule of Law in Vietnam: Theory and Practice" in Rule Law Perspect Pacfic Rim (Mansfield Center for Pacific Affairs, 2000).

Tuấn, N M. Nhũng giá trị tích cực của Nho giáo trong Bộ luật Hồng Đức, 4 (Hanoi: Tạp chí Khoa học, Đại học Quốc gia Hà nội, Chuyên san Kinh tế, 2004).

Vu, C G \& K Tran. "Constitutional Debate and Development on Human Rights in Vietnam" (2016) 1 Asian J Comp Law.

$\mathrm{Vu}$, Cong Giao, Minh Tuan Nguyen \& Minh Tuan Dang. Report Assessment of the Legislative Development Process in Vietnam since adoption of 2013 Constitution (Hanoi: National Legislative Development Project, 2004).

Vo, Van Ai. "Human Rights and Asian Values in Vietnam" in Hum Rights Asian Values Contesting Natl Identities Cult Represent Asia, Studies in Asian Topics 6 (Routledge, 2000). 
Zakaria, Fareed. "A Conversation with Lee Kuan Yew", Foreign Aff (1 March 1994), online: <https://www.foreignaffairs.com/articles/asia/1994-03-01/conversation-leekuan-yew>.

Zakaria, Fareed. “Asian Values”, (2002), online: Foreign Policy <https://foreignpolicy.com/2009/11/09/the-dustbin-of-history-asian-values/>.

Vu Cong Giao is an expert on human rights law in Vietnam, with nearly 20 years researching and teaching in the field. He has finished and coordinated hundreds research projects, workshops and conferences on human rights and constitutional laws since 1996. Giao is currently Head of the Department of Constitutional and Administrative Laws, School of Law, Vietnam National University Hanoi (VNU-LS). He initiated and played the key role in running VNU-LS's Master's Program in Human Rights Laws, the first of its kind in Vietnam. Between 2011and 2013 Giao was highly engaged in discussions on amending the chapter on human rand civil rights in Vietnam's 1992 Constitution (now the Constitution of 2013). Contact: giaovnu@gmail.com

Ngo Huong is a human rights and development expert in Vietnam. Her $\mathrm{PhD}$ is in Human Rights and Peace Studies from Mahidol University (Thailand). She holds Masters degrees in Public International Law (LLM) and Human Rights (M.Phil.) from the University of Oslo, and in Development Management from the Asian Institute of Management, Philippines. Dr Ngo currently coordinates the Master's programme on Human Righ ts Laws in the School of Law, Vietnam National University, Hanoi. She was Chair of the Capacity Building Committee of the Southeast Asian Human Rights and Peace education programme (SHAPE-SEA) in Thailand from 2011 to 2016. She is the co-founder of the Center for Development and Integration Vietnam (Vietnamese NGO). Dr Ngo has also worked at the Asian Development Bank, NORAD and other NGOs in Vietnam. Contact: nmhuongvn@gmail.com

Nguyen Minh Tam is a PhD student in International Law at School of Law, Hunan Normal University (China). He holds a master degree in International Human Rights Law (LLM) from School of Law, Vietnam National University Hanoi (VNU- LS). His research interests are in constitutional and human rights laws, under the supervisor of Dr. Vu Cong Giao. For the last three years, he has accomplished and published more than ten scientific papers. Contact khajtam2012@yahoo.com 